Supporting Materials for

\title{
Decadal Geochemical and Isotopic Trends for Nitrate in the Transboundary Abbotsford-Sumas Aquifer and Implications for Agricultural Beneficial Management Practices
}

Leonard I. Wassenaar ${ }^{{ }^{*}}$, M. Jim Hendry ${ }^{2}$ and Nikki Harrington ${ }^{3}$

\footnotetext{
${ }^{* 1}$ Environment Canada, 11 Innovation Blvd. Saskatoon, SK, Canada, S7N 3H5

${ }^{2}$ Department of Geological Sciences, University of Saskatchewan, Saskatoon, SK, Canada, S7N 5E2

${ }^{3}$ Department of Water, Land and Biodiversity Conservation, 11 Helen St. P.O. Box 1246, Mount Gambier SA 5290, Australia
}

\footnotetext{
*Corresponding Author: Leonard I. Wassenaar, Environment Canada, 11 Innovation Blvd., Saskatoon, SK, Canada, S7N 3H5. telephone: (306) 975-5747 e-mail address:

len.wassenaar@ec.gc.ca
} 


\section{Materials and Methods}

Aquifer Hydrogeology

The Abbotsford-Sumas aquifer is a transboundary sand and gravel aquifer in southwestern British Columbia and northern Washington State (Figure S-1). It is typically between 10 and $25 \mathrm{~m}$ thick, but reaches nearly $60 \mathrm{~m}$ thickness in the northeast part of the aquifer. The depth to the water table ranges from a few meters to over 10 meters, with annual water table fluctuations of as much as 2 meters. These annual fluctuations correlate with heavy fall and winter precipitation events (1-3). The general flow direction in the aquifer is towards the south, southeast, and southwest at estimated average linear velocities of up to $450 \mathrm{~m} / \mathrm{yr}(2,3)$. The aquifer is highly vulnerable to surface derived contamination due to its coarse sand and gravel texture and because the area receives precipitation of about $1500 \mathrm{~mm} / \mathrm{yr}$, of which $75 \%$ occurs as rainfall between October and March when nutrient uptake by crops are lowest and soil nitrate leaching potential is highest. It is estimated that between $40-80 \%$ of annual precipitation enters the aquifer, resulting in recharge rates of about 2-3 meters per year $(3,4)$.

\section{Sample Collection and Analysis}

Groundwater samples were collected from a combination of monitoring, domestic, and municipal wells in September 2004 ( $n=70$; Table S-1). The well selection strategy was aimed at re-sampling the same wells studied in 1993 by Wassenaar(5). Groundwater was pumped from monitoring wells using a 2-stage submersible pump, and from domestic and municipal wells using existing infrastructure. In all cases, groundwater was pumped directly through a flow-through cell housing a Hydrolab® multi-probe mini-Sonde (temperature, $\mathrm{pH}$, electrical conductivity, redox potential, dissolved oxygen). Samples for water chemistry, isotopes of water and dissolved nitrate were collected after at least three casing volumes were removed from the wells and the Hydrolab® field parameters had stabilized. For domestic wells, samples were collected and Hydrolab measurements made prior to the treatment system or pressure tank.

Water samples for nitrate and major and minor ion concentrations were filtered through $0.45 \mu \mathrm{m}$ cellulose acetate membrane filters into $125 \mathrm{~mL}$ HDPE bottles, stored at $5^{\circ} \mathrm{C}$, and analyzed using standard ion chromatographic techniques using a Dionex 2000 
ion chromatograph. Nitrate results are reported as $\mathrm{mg} \mathrm{NO}_{3}{ }^{-} / \mathrm{L}$. $\mathrm{NO}_{2}{ }^{-}$and $\mathrm{NH}_{4}$ were measured on all samples but only 6 samples had detectable $\mathrm{NO}_{2}{ }^{-}$concentrations below $1 \mathrm{mg} / \mathrm{L}$.

Samples for isotope analyses on nitrate $\left(\delta^{15} \mathrm{~N}\right.$ and $\left.\delta^{18} \mathrm{O}\right)$ were filtered through $0.45 \mu \mathrm{m}$ cellulose acetate membrane filters and stored cold in $125 \mathrm{ml} \mathrm{HDPE}$ bottles. Nitrate isotope assays were conducted at the USGS Isotope Laboratory in Reston, VA, using methods described elsewhere $(6,7)$. All $\delta^{15} \mathrm{~N}$ values are reported relative to the atmospheric air standard (8) and normalized by analyzing reference materials IAEA-N3 $(+4.7 \% \circ),(+180 \% \circ)$, USGS34 (-1.8\%o), USGS35 (+2.7\%o) along with samples. The analytical error for $\delta^{15} \mathrm{~N}$ is $\pm 0.5 \%$. All nitrate $\delta^{18} \mathrm{O}$ values were reported relative to the VSMOW standard (9) and determined by analyzing reference materials IAEA-N3 (+25.6), USGS32 (+25.7\%), USGS34 (-27.9\%॰), and USGS35 (+57.5\%॰). The analytical error for nitrate $\delta^{18} \mathrm{O}$ is $\pm 1.0 \%$. To facilitate comparison to the 2004 data, the 1993 nitrate $\delta^{18} \mathrm{O}$ data of Wassenaar (5) had to be adjusted for scale compression that from the sealed-tube combustion technique (10). This adjustment was done by re-analyzing laboratory references materials analyzed in 1993 for which values were not well known at that time. These included USGS32 and UFZ1 working standard which yielded a $\delta^{18} \mathrm{O}$ value of $+14.1 \%$ at the USGS Reston lab in 2005 .

Samples for tritium $\left({ }^{3} \mathrm{H}\right)$ analyses $(n=18)$ were collected in November 2004 in $1 \mathrm{~L}$ glass bottles and analyzed at the University of Waterloo, Canada, by liquid scintillation counting. The tritium analyses were reported to a precision of $\pm 0.6 \mathrm{TU}$. Dissolved permanent and noble gas samples were collected in November 2004 from the same wells that were sampled for ${ }^{3} \mathrm{H}$. Sampling was carried out using in situ diffusion gas samplers. The in situ diffusion sampler method is described in detail by others(11) and consisted of small copper tubes with an internal headspace volume of approximately 0.3 $\mathrm{cm}^{3}$ and gas-permeable silicone membranes. The diffusion samplers were lowered to the well intake zone and left to equilibrate for $24 \mathrm{hrs}$. The samplers were quickly brought to the surface and cold-weld sealed. Concentrations of noble ( $\mathrm{He}, \mathrm{Ne}, \mathrm{Ar}, \mathrm{Kr}$, and $\mathrm{Xe}$ ) and permanent gases, and ${ }^{3} \mathrm{He} /{ }^{4} \mathrm{He}$ ratio were determined on a magnetic sector-field and quadrupole mass spectrometer at the University of Utah. 
Groundwater ages were determined using the ${ }^{3} \mathrm{H} /{ }^{3} \mathrm{He}$ dating method (12) using algorithms to account for excess ${ }^{3} \mathrm{He}$ by determining the amount of excess air using $\mathrm{N}_{2} /$ Ar ratios and Neon gas concentrations (13). The error in the corrected ages is \pm 0.5 years, which was considered to be acceptable for this study. ${ }^{3} \mathrm{H} /{ }^{3} \mathrm{He}$ ages represent the travel time since entering groundwater, therefore wells with long screens were avoided to prevent mixing with variable-age water.

Long-term nitrate data from selected monitoring wells used in this study were obtained from the groundwater quality monitoring databases maintained by Environment Canada (1989-2004). Statistical analyses were performed using Minitab Release 14 (www.minitab.com), and multivariate time series analyses were conducted using the Mann-Kendall method for the determination of trends $(14,15)$. 


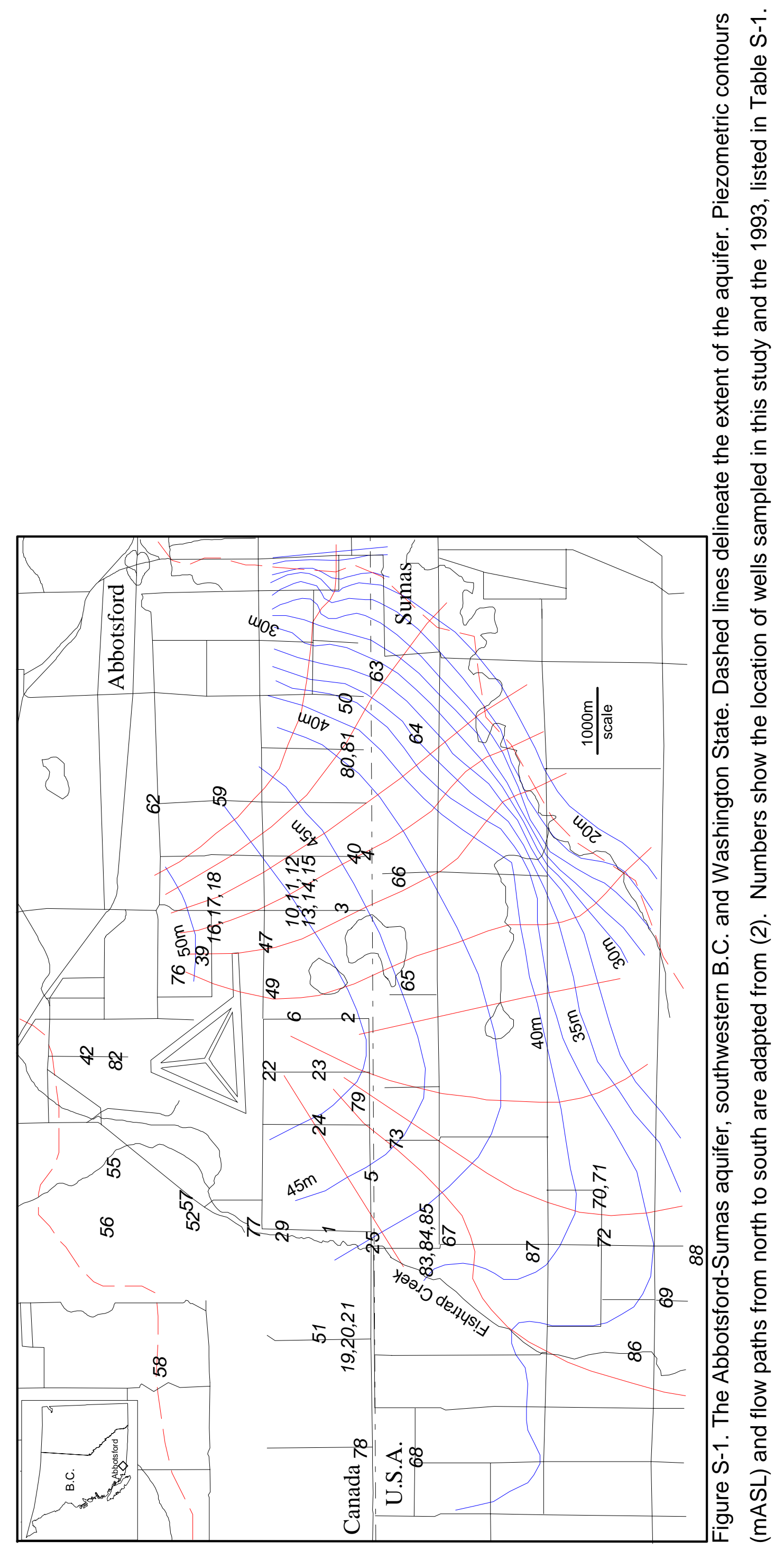


Table S-1. Abbotsford-Sumas aquifer sampling sites, nitrate concentrations $\left(\right.$ as $\left.\mathrm{NO}_{3}{ }^{-}\right)$and isotopic composition of nitrate in September 2004 and February 1993. Map \# refers to site locations in Figure S-1. Nitrate oxygen isotopes are in permil (\%o) relative to VSMOW reference. The $\delta^{15} \mathrm{~N}$ of nitrate are in permil (\%o)relative to Air reference. Groundwater ages determined using ${ }^{3} \mathrm{H}-{ }^{3} \mathrm{He}$ method. Site 25 was not included in statistical assessments in the main text due to being highly denitrified and may have had a ruptured casing.

\begin{tabular}{|c|c|c|c|c|c|c|c|c|}
\hline Map & Well ID & $\begin{array}{c}\text { Depth BG } \\
\text { (m) }\end{array}$ & $\begin{array}{c}\mathrm{NO}_{3}^{-} \\
\mathbf{~ m g / L} \\
2004\end{array}$ & $\begin{array}{l}\delta^{15} \mathbf{N} \\
\mathbf{N O}_{3}^{-} \\
2004\end{array}$ & $\begin{array}{l}\delta^{18} \mathbf{O} \\
\mathbf{N O}_{3}^{-} \\
2004\end{array}$ & $\begin{array}{r}\mathbf{N O}_{3}^{-} \\
\mathbf{~ m g / L ~} \\
1993\end{array}$ & $\begin{array}{c}\delta^{\mathbf{1 5}} \mathbf{N} \\
\mathbf{N O}_{\mathbf{3}}^{-} \\
1993\end{array}$ & $\begin{array}{c}{ }^{3} \mathbf{H}-{ }^{3} \mathrm{He} \\
(\mathbf{y r s}) \\
\text { Age }\end{array}$ \\
\hline & Piezometers & & & & & & & \\
\hline 1 & $\mathrm{ABB} 1$ & 8.0 & 62.1 & 24.8 & +5.3 & 21.2 & 14.0 & $\mathrm{n} / \mathrm{a}$ \\
\hline 2 & $\mathrm{ABB} 2$ & 7.8 & 31.7 & 5.4 & -4.8 & 61.5 & 7.5 & 5.5 \\
\hline 3 & ABB3 & 18.0 & 93.3 & 9.9 & +2.2 & 45.4 & 5.5 & 0.9 \\
\hline 4 & $\mathrm{ABB} 4$ & 30.0 & 107.0 & 11.4 & -1.6 & 85.8 & 14.9 & $\mathrm{n} / \mathrm{a}$ \\
\hline 5 & ABB5 & 9.5 & 140.0 & 8.8 & +0.7 & 72.7 & 8.9 & 4.3 \\
\hline 6 & ABB6 & 10.0 & 48.0 & 8.8 & -1.4 & 48.3 & 6.1 & $\mathrm{n} / \mathrm{a}$ \\
\hline 10 & $91-1$ & 10.0 & 88.1 & 10.2 & -1.6 & 56.2 & 12.3 & 14.7 \\
\hline 11 & $91-2$ & 22.9 & 108.0 & 9.8 & -1.1 & 69.1 & 11.4 & $\mathrm{n} / \mathrm{a}$ \\
\hline 12 & $91-3$ & 19.2 & 110.0 & 9.4 & -1.2 & 65.9 & 11.0 & 3.5 \\
\hline 13 & $91-4$ & 46 & 70.7 & 9.0 & -1.7 & 49.0 & 9.7 & 10.7 \\
\hline 14 & $91-5$ & 45.3 & 89.9 & 10.3 & -2.2 & 58.1 & 11.2 & 7.8 \\
\hline 15 & $91-7$ & 22.0 & 55.9 & 6.9 & -2.2 & 44.9 & 9.7 & 2.7 \\
\hline 16 & $91-8$ & 33.5 & 126.0 & 10.6 & -2.3 & 60.5 & 15.3 & $\mathrm{n} / \mathrm{a}$ \\
\hline 17 & $91-9$ & 28.0 & 102.0 & 18.7 & 2.5 & 73.4 & 12.9 & $\mathrm{n} / \mathrm{a}$ \\
\hline 18 & $91-10$ & 13.5 & 106.0 & 13.3 & -0.3 & 118.0 & 12.9 & $\mathrm{n} / \mathrm{a}$ \\
\hline 19 & $91-13$ & 20.8 & 84.0 & 7.8 & +10.6 & 92.9 & 11.2 & $\mathrm{n} / \mathrm{a}$ \\
\hline 20 & $91-15$ & 11.4 & 90.9 & 10.9 & +0.6 & 80.4 & 11.4 & $\mathrm{n} / \mathrm{a}$ \\
\hline 21 & $91-16$ & 14.4 & 38.5 & 5.5 & -2.8 & 42.0 & 4.5 & $\mathrm{n} / \mathrm{a}$ \\
\hline $22 *$ & BC-A-25 & 7.6 & 20.0 & 2.1 & -0.6 & 19.6 & 8.8 & 4.2 \\
\hline 22 & BC-A-35 & 10.7 & 26.6 & 4.0 & -1.4 & 13.3 & 6.2 & $\mathrm{n} / \mathrm{a}$ \\
\hline 22 & BC-A-55 & 16.8 & 20.4 & 6.1 & -1.3 & 19.2 & 7.6 & $\mathrm{n} / \mathrm{a}$ \\
\hline 22 & BC-A-75 & 22.9 & 23.4 & 21.7 & +4.5 & 26.0 & 7.5 & 19.1 \\
\hline $23 *$ & BC-B-20 & 6.1 & 69.6 & 6.9 & -2.6 & 62.8 & 8.8 & 1.3 \\
\hline 23 & BC-B-35 & 10.7 & 63.1 & 7.3 & -2.8 & 74.1 & 10.8 & $\mathrm{n} / \mathrm{a}$ \\
\hline 23 & BC-B-55 & 16.8 & 29.3 & 8.2 & -2.9 & 50.3 & 11.1 & $\mathrm{n} / \mathrm{a}$ \\
\hline 23 & BC-B-75 & 22.9 & 8.8 & 15.3 & +3.0 & 15.1 & 18.2 & 20.4 \\
\hline $24 *$ & BC-C-25 & 7.6 & 65.9 & 4.7 & -0.4 & 36.9 & 6.1 & 1.5 \\
\hline 24 & BC-C-35 & 10.7 & 103.0 & 8.9 & -2.1 & 67.6 & 8.4 & $\mathrm{n} / \mathrm{a}$ \\
\hline 24 & BC-C-75 & 22.9 & 7.2 & 15.5 & +2.3 & 12.1 & 19.6 & 32.9 \\
\hline 25 & FT1-24 & 7.3 & 6.7 & 71.9 & +25.7 & bd & $\mathrm{n} / \mathrm{a}$ & $\mathrm{n} / \mathrm{a}$ \\
\hline $29 *$ & FT5-12 & 3.7 & 55.0 & 9.2 & -1.2 & 95.7 & 10.6 & $\mathrm{n} / \mathrm{a}$ \\
\hline 29 & FT5-25 & 7.6 & 56.8 & 9.7 & -1.4 & 65.9 & $\mathrm{n} / \mathrm{a}$ & $\mathrm{n} / \mathrm{a}$ \\
\hline 29 & FT5-40 & 12.2 & 41.2 & 9.9 & -0.8 & $\mathrm{~b} / \mathrm{d}$ & $\mathrm{n} / \mathrm{a}$ & $\mathrm{n} / \mathrm{a}$ \\
\hline 78 & US2 & 6.7 & 286.0 & 14.7 & +1.9 & $\mathrm{n} / \mathrm{a}$ & $\mathrm{n} / \mathrm{a}$ & $\mathrm{n} / \mathrm{a}$ \\
\hline 79 & US4 & 11.5 & 66.9 & 7.6 & -2.7 & $\mathrm{n} / \mathrm{a}$ & $\mathrm{n} / \mathrm{a}$ & $\mathrm{n} / \mathrm{a}$ \\
\hline 80 & US945H-26 & 25.5 & 56.1 & 4.8 & +2.6 & $\mathrm{n} / \mathrm{a}$ & $\mathrm{n} / \mathrm{a}$ & 9.2 \\
\hline 81 & US945H-29 & 29.0 & 37.0 & 7.5 & +5.7 & $\mathrm{n} / \mathrm{a}$ & $\mathrm{n} / \mathrm{a}$ & 19.1 \\
\hline \multirow[t]{3}{*}{82} & 99-Q-14 & 14 & 71.1 & 9.4 & -1.2 & $\mathrm{n} / \mathrm{a}$ & $\mathrm{n} / \mathrm{a}$ & 4.2 \\
\hline & 99-Q-20 & 20 & 46.3 & 8.9 & -1.0 & $\mathrm{n} / \mathrm{a}$ & $\mathrm{n} / \mathrm{a}$ & 19.1 \\
\hline & 99-Q-27 & 27 & 51.6 & 9.8 & -0.6 & $\mathrm{n} / \mathrm{a}$ & $\mathrm{n} / \mathrm{a}$ & $\mathrm{n} / \mathrm{a}$ \\
\hline 84 & ABS407 & 13.1 & 23.0 & 23.9 & +7.4 & $\mathrm{n} / \mathrm{a}$ & $\mathrm{n} / \mathrm{a}$ & $\mathrm{n} / \mathrm{a}$ \\
\hline 85 & ABS409 & 5.5 & 31.7 & 4.1 & -0.4 & $\mathrm{n} / \mathrm{a}$ & $\mathrm{n} / \mathrm{a}$ & $\mathrm{n} / \mathrm{a}$ \\
\hline 86 & ABS493 & 7 & 55.0 & 6.5 & +5.2 & $\mathrm{n} / \mathrm{a}$ & $\mathrm{n} / \mathrm{a}$ & $\mathrm{n} / \mathrm{a}$ \\
\hline 87 & ABS402 & 7.3 & 117.8 & 6.6 & +0.3 & $\mathrm{n} / \mathrm{a}$ & $\mathrm{n} / \mathrm{a}$ & $\mathrm{n} / \mathrm{a}$ \\
\hline \multirow[t]{2}{*}{88} & ABS401 & $\mathrm{n} / \mathrm{a}$ & 5.5 & 5.3 & +1.2 & $\mathrm{n} / \mathrm{a}$ & $\mathrm{n} / \mathrm{a}$ & $\mathrm{n} / \mathrm{a}$ \\
\hline & $\begin{array}{c}\text { Domestic and } \\
\text { Municipal } \\
\text { Wells }\end{array}$ & & & & & & & \\
\hline 39 & 226 & 19.8 & 42.7 & 14.0 & +0.4 & 48.9 & 16.0 & $\mathrm{n} / \mathrm{a}$ \\
\hline 40 & 228 & 39.9 & 112.0 & 11.2 & -1.8 & 60.5 & 13.6 & $\mathrm{n} / \mathrm{a}$ \\
\hline 42 & 232 & 13.7 & 12.7 & 5.0 & -1.8 & 18.8 & 11.1 & $\mathrm{n} / \mathrm{a}$ \\
\hline
\end{tabular}




\begin{tabular}{|c|c|c|c|c|c|c|c|c|}
\hline 47 & 238 & 31.1 & 42.1 & 4.6 & -2.2 & 53.7 & 7.3 & $\mathrm{n} / \mathrm{a}$ \\
\hline 49 & 240 & 18.6 & 17.1 & 7.6 & -2.6 & 16.7 & 5.6 & $\mathrm{n} / \mathrm{a}$ \\
\hline 50 & 241 & 17.7 & 4.1 & 11.1 & -1.2 & 38.1 & 11.0 & $\mathrm{n} / \mathrm{a}$ \\
\hline 51 & 243 & 4.6 & 12.1 & 28.1 & +7.3 & 151.0 & 14.4 & $\mathrm{n} / \mathrm{a}$ \\
\hline 52 & 244 & 33.5 & 20.1 & 7.2 & -0.6 & 40.5 & 9.6 & $\mathrm{n} / \mathrm{a}$ \\
\hline 55 & 247 & 10.8 & 32.3 & 5.8 & -0.8 & 40.7 & 10.9 & $\mathrm{n} / \mathrm{a}$ \\
\hline 56 & 248 & 50.6 & 30.2 & 4.7 & -1.6 & 32.6 & 2.1 & $\mathrm{n} / \mathrm{a}$ \\
\hline 57 & 249 & 18.0 & 54.7 & 7.2 & -1.5 & 100.0 & 13.1 & $\mathrm{n} / \mathrm{a}$ \\
\hline 58 & 250 & 29.0 & 30.7 & 10.8 & -2.4 & 34.8 & 15.3 & $\mathrm{n} / \mathrm{a}$ \\
\hline 59 & 252 & 49.7 & 22.2 & 8.1 & -2.5 & 48.0 & 11.3 & $\mathrm{n} / \mathrm{a}$ \\
\hline 62 & 255 & 26.8 & 81.7 & 9.9 & -2.3 & 100.0 & 12.5 & $\mathrm{n} / \mathrm{a}$ \\
\hline 63 & Sumas \#4** & 21.0 & 18.4 & 14.0 & +1.6 & 26.4 & $\mathrm{Na}$ & $\mathrm{n} / \mathrm{a}$ \\
\hline 64 & May Rd. \#3** & 21.9 & 47.7 & 9.0 & -1.4 & 60.3 & 10.3 & $\mathrm{n} / \mathrm{a}$ \\
\hline 65 & Holmquist & 11.3 & 63.0 & 8.5 & +0.5 & 118.0 & 16.0 & $\mathrm{n} / \mathrm{a}$ \\
\hline 66 & Jahns & 24.4 & 49.8 & 5.1 & -0.8 & 29.9 & 2.9 & $\mathrm{n} / \mathrm{a}$ \\
\hline 67 & Honcoop & 8.8 & 37.5 & 4.0 & -0.5 & 51.9 & 3.9 & $\mathrm{n} / \mathrm{a}$ \\
\hline 69 & Assink & 7.6 & 113.7 & 5.4 & +2.6 & 119.0 & 15.9 & $\mathrm{n} / \mathrm{a}$ \\
\hline 69 & Helgath & 8.8 & 79.7 & 2.4 & +2.1 & 49.1 & 2.5 & $\mathrm{n} / \mathrm{a}$ \\
\hline 70 & Gilmore & 11.0 & 107.0 & 6.1 & +0.1 & 45.7 & 7.1 & $\mathrm{n} / \mathrm{a}$ \\
\hline 71 & Gilmore \#2 & 13.4 & 85.7 & 6.5 & +1.1 & 52.1 & 7.4 & $\mathrm{n} / \mathrm{a}$ \\
\hline 72 & Covenant & 9.1 & 72.9 & 4.4 & +0.4 & 61.6 & 6.0 & $\mathrm{n} / \mathrm{a}$ \\
\hline 73 & Coon & 7.6 & 5.3 & 6.3 & +0.2 & 83.9 & 11.8 & $\mathrm{n} / \mathrm{a}$ \\
\hline \multicolumn{9}{|c|}{ Surface Waters } \\
\hline 76 & Gravel Pit & 0 & 37.4 & 15.9 & +1.2 & 55.8 & 16.0 & $\mathrm{n} / \mathrm{a}$ \\
\hline 77 & Fishtrap Creek & 0 & 3.1 & 11.3 & +2.3 & 22.5 & 13.2 & $\mathrm{n} / \mathrm{a}$ \\
\hline
\end{tabular}

*- multilevel piezometer. $\mathrm{n} / \mathrm{a}$ - not measured. bd - below detection limit of $0.02 \mathrm{mg} \mathrm{NO}_{3} \mathrm{~L}^{-1}$ **municipal supply well 


\section{Supporting References}

1. Kohut, A. P., Sather, S., Kwong, J., and Chowijka, K. (1989) Nitrate contamination of the Abbotsford aquifer. B.C. Ministry of Water, Land and Air Protection. $18 \mathrm{pp}$.

2. Liebscher, H., Hi, B., and McNaughton, D. (1992) Nitrates and pesticides in the Abbotsford aquifer, Southwestern British Columbia. Environment Canada. 83p.

3. Cox, S. E., and Kahle, S. C. (1999) Hydrogeology, groundwater quality and sources of nitrate in lowland glacial aquifers of Whatcom county, Washington and British Columbia, Canada. USGS Water Resources Investigation Report 984195

4. Kohut, A. P. (1987) Groundwater supply capability. B.C. Ministry of Water, Land and Air Protection. $18 \mathrm{pp}$

5. Wassenaar, L. I. (1995) Evaluation of the Origin and Fate of Nitrate in the Abbotsford Aquifer Using the Isotopes of N-15 and O-18 in NO3, Applied Geochemistry 10, 391-405.

6. Casciotti, K. L., Sigman, D. M., Hastings, M. G., Bohlke, J. K., and Hilkert, A. (2002) Measurement of the oxygen isotopic composition of nitrate in seawater and freshwater using the denitrifier method, Analytical Chemistry 74, 4905-4912.

7. Sigman, D. M., Casciotti, K. L., Andreani, M., Barford, C., Galanter, M., and Bohlke, J. K. (2001) A bacterial method for the nitrogen isotopic analysis of nitrate in seawater and freshwater, Analytical Chemistry 73, 4145-4153.

8. Mariotti, A. (1983) Atmospheric nitrogen is a reliable standard for natural $15 \mathrm{~N}$ abundance measurements, Nature 303, 685-687.

9. Coplen, T. B. (1994) Reporting of Stable Hydrogen, Carbon, and Oxygen Isotopic Abundances, Pure and Applied Chemistry 66, 273-276.

10. Revesz, K., and Bohlke, J. K. (2002) Comparison of O-delta 18 measurements in nitrate by different combustion techniques, Analytical Chemistry 74, 5410-5413.

11. Sheldon, A. (2002) Diffusion of radiogenic helium in shallow ground water: Implications for crustal degassing, in Department of Geology and Geophysics, University of Utah, Salt Lake City.

12. Tolstikhin, I. N., and Kamenskiy, I. L. (1969) Determination of groundwater age by the T-3He method, Geochemistry International Ussr 6, 810-811.

13. Solomon, D. K., and Cook, P. G. (2000) $3 \mathrm{H}$ and $3 \mathrm{He}$, in Environmental tracers in subsurface hydroogy (Cook, P., and Herczeg, A. L., Eds.), Kluwer Academic Publishers, Boston.

14. Lettenmaier, D. P. (1988) Multivariate Nonparametric-Tests for Trend in WaterQuality, Water Resources Bulletin 24, 505-512.

15. Thas, O., Van Vooren, L., and Ottoy, J. P. (1998) Nonparametric test performance for trends in water quality with sampling design applications, Journal of the American Water Resources Association 34, 347-357. 
